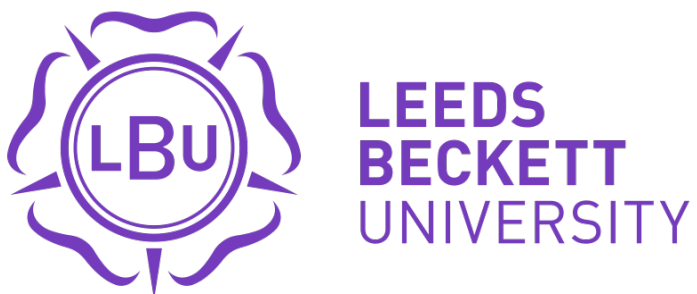

\section{Citation:}

Gondim Mariutti, F and Tench, R (2015) How does Brazil measure up? Comparing rankings through the lenses of nation brand indexes. Place Branding and Public Diplomacy. ISSN 1751-8059 DOI: https://doi.org/10.1057/pb.2015.19

Link to Leeds Beckett Repository record:

https://eprints.leedsbeckett.ac.uk/id/eprint/2020/

Document Version:

Article (Accepted Version)

Date of Acceptance: 2nd November 2015

The aim of the Leeds Beckett Repository is to provide open access to our research, as required by funder policies and permitted by publishers and copyright law.

The Leeds Beckett repository holds a wide range of publications, each of which has been checked for copyright and the relevant embargo period has been applied by the Research Services team.

We operate on a standard take-down policy. If you are the author or publisher of an output and you would like it removed from the repository, please contact us and we will investigate on a case-by-case basis.

Each thesis in the repository has been cleared where necessary by the author for third party copyright. If you would like a thesis to be removed from the repository or believe there is an issue with copyright, please contact us on openaccess@leedsbeckett.ac.uk and we will investigate on a case-by-case basis. 


\title{
How does Brazil measure up? Comparing rankings through the lenses of nation brand indexes
}

\begin{abstract}
A considerable amount of literature has been published on nation brand and yet not much regarding measurement. The purpose of this paper is to examine nation brand indexes and explore the unbalanced outcomes of a country's position in these recognized instruments. Although research has been carried out on nation brand, no single study exists comparing a country in four diverse nation brand indexes, which are the reputable ones by Anholt (2007), Fetscherin (2010), Fombrun (2014) and Anholt and Govers (2014). This paper also reflects on the critical studies perspective of the place branding research domain, discussed by Lucarelli and Berg (2011). After a qualitative approach applied to Brazil, it is believed that these indexes mutually support and complement each other even though they use different approaches, methodologies, samples, and data. Moreover, each of them has their own strengths and weaknesses in terms of accuracy and rationality. Findings from this paper's evaluation may guide nation brand managers, governments, and researchers to recognize that indexes should be taken into account when analysing a nation brand and its complex image. Therefore, this paper contributes to existing knowledge on the critical studies perspective of the contemporary theoretical structure of the place branding research domain by providing a comparative study based on real data-based rankings of nation brand indexes.
\end{abstract}

Keywords: nation brand indexes; nation brand rankings; country brand rankings; country brand image; Brazil’s brand image.

\section{Introduction}

Understanding the positioning of a nation brand in the international business context is a vital practice both in academic circles and in the corporate environment and it demands critical thinking and evaluative expertise. To start with, Florek et al. (2006) highlight that a place is a multiplex system and branding is a continuously evolving process; as many authors do support as well (Ashworth and Kavaratzis, 2010; Braun and Zenker, 2010; Buhmann and Ingenhoff, 2013; Dinnie, 2009; Gertner; 2011; Go and Gover, 2011; Kavaratzis, 2005; Lucarelli and Brorström, 2013; Moilanen and Rainisto, 2009; Warnaby and Medway, 2013).

Debate in academic circles continues about the best approach or philosophy for the management of a place brand or a nation brand. Correspondingly, government bureaus have a duty to play an appropriate role in supporting the country reputation and promoting the nation brand or its dimensions; it is usually being continuously promoted with or without private sector involvement. 
Stakeholders instantaneously may perceive the overall image of a country when it is internationally promoted, exposed or broadcasted. Additionally, one of the most significant current discussions in nation brand and its image studies is how international business, marketing, and communications professionals can use a nation's brand as a differentiating tool for the development of the country (Dinnie, 2016), when successfully planned, applied, and studied. Moreover, “in recent years, nation branding has steadily gained prominence in practice as more and more countries around the world commit resources to the development of their nation brand” (Dinnie, 2016, p.4).

Throughout this paper, the term 'nation brand' will refer to 'country brand' as identical terminologies for the models and indexes setting. Thus, also the terms 'model' and 'index' are used interchangeably and their meaning is a method to measure a nation brand construct in order to present a comprehensive, logical and unbiased ranking.

The main reason for advancing with nation brand indexes and models is that they provide strategic insights for the development of the country per se, when successfully managed and researched. As one of the main purposes of place branding is to improve the place's image, then successful measurement is an essential tool (Zenker and Martin, 2011). Furthermore, "as a social phenomenon, a place brand is based on the perceptions of target audiences - which might or might not be influenced by the physical and communicative aspects of a given city” (Sevin, 2014, p.48). As suggested by Fetscherin (2010, p.475), “countries could then attempt to strengthen the country brand by taking appropriate actions”. The actions encompass government procedures and the administrative decisions - moreover, political and administrative policymaking is fundamental to place marketing and branding as well (Braun and Zenker, 2010).

Therefore, this paper attempts to contribute to the knowledge of the field by adding to the literature regarding place branding studies which can directly support nation brand managers and government authorities in considering nation brand indexes to improve understanding of a country brand. Consequently, the purpose of this study is to examine the similarities and differences 
regarding nation brand indexes globally, having Brazil as a unit of analysis, in order to reflect critically about their outcomes and advance further regarding improvements for the country brand image and the political actions for the country enhancements. Additionally, due to the influential factors of multidimensionality and multidisciplinary origins of nation brands - politicians and place brand managers need measurement tools to plan and/or justify their investments. For instance, even though relying on nation place rankings may not be the only appropriate solution for understanding a country brand, this paper attempts to enlighten the research domain. Perhaps, when place brand indexes are integrated with other models based on place branding approaches for analysis and investigation, whether supported by theoretically based research or consultancy customized, the overall measurement may convey a more reliable perception for country brand decision-makers.

According to Zenker (2011, p.40), there is lack of "proper conceptualization of a place brand that employs different measurement approaches for the different elements of the brand”. Hence, as part of the contribution of this research, this paper analyses four key nation brands to convey the difference between perception-based and real data-based rankings. Using four indexes as examples for understanding a country brand - Anholt (2007), Fetscherin (2010), Fombrun (2014) and Anholt and Govers (2014) - this paper contributes to the understanding of the measurement of nation brands.

This paper's research is focused on the example of the Brazil as a brand. This is mainly because there is a need for more studies of Brazil's image, which is seen as dichotomous and confusing because of its positive and negative attributes and associations (Mariutti and Giraldi, 2013; Kotler and Keller, 2006; Beni, 2006; Bignami, 2002). Furthermore, for Goulart (2015), Brazil’s brand has fragile associations. This research is carried out by using an exploratory qualitative approach which is applied through a case study about Brazil.

Regarding the structure of this paper, initially the literature is reviewed critically, followed by the presentation of a brief methodology, and concluded by the final discussion. In the literature review, this paper reflects on a nation brand construct's characteristics and country brand 
measurement through the place branding perspective; after, it describes the case of Brazil. Next, it details the leading branding indexes in order to present briefly Brazil's brand positions in seven of them. Moreover, it moves forward to compare the most four indexes regarding their own concept in order to compare them in detail, aligning to Brazil’s position(s) in each one of them. Fundamentally, this paper reflects upon the expansion of the theory of country brand measurement in order to strategically analyse a country's brand abroad through nation brand indexes and consider their relative ranking positions and their respective purposes. The paper acknowledges that models for a complex place such as cities - or even countries - cannot be entirely precise, but at least be productive for research and theory development (Zenker, 2011). Importantly, in this research, the 'ranking positions' are assumed to be an indicator for the communicated reputation of a nations' brand, which could build, change, or enhance people's perceptions of their country image.

\section{Literature Review}

\section{Country Brand Measurement's Role in Place Branding}

Over the last thirty years, theoretical studies have emerged rapidly about branding a place and have steadily achieved distinction (Warnaby and Medway, 2013; Gertner, 2011; Kavaratziz, 2010; Moilanen and Rainisto, 2009; Dinnie, 2009); both the academic and practical research have been increasing significantly (Zenker, 2014; Gertner, 2011; Lucarelli and Berg, 2011) as well. For the place reputation scholar and advisor Robert Govers (Place Brand Observer, 2014), place branding is a significant discipline with interdisciplinary underpinning and tremendous potential. Emphatically, any place can be defined as branded, for instance, a country, a city, a university, a building, an airport, a park, a stadium, a beach, a mountain. Florek et al. (2006, p.294) point out that "place branding should lead to distinguishing the place among others”.

Place branding is not a new topic in academia. There has been a considerable intensification and acceptance of the concept of nation branding in the last decade (Cevero, 2013; Ashworth and 
Kavaratzis, 2010; Fetscherin, 2010; Szondi, 2007) - in both academic and corporate environments (Sevin, 2014; Warnaby and Medway, 2013; Gertner; 2011; Go and Gover, 2011; Ashworth and Kavaratzis, 2010; Dinnie, 2009; Kotler and Keller, 2006). Moreover, as city branding stands as a heterogeneous research domain where there is a cross-disciplinary mix of studies (Lucarelli and Berg, 2011), so does country branding. Given the fact that the theoretical context of place branding can be grounded on several disciplines, such as, place marketing (Moilanen and Rainisto, 2009; Kotler, Haider and Rein, 1993); international marketing (Papadopoulos and Heslop, 1993); public diplomacy (Gertner, 2011; Moilanen and Rainisto, 2009; Jansen, 2008; Anholt, 2000, 2007); country of origin image (Roth and Diamantopoulos, 2008; Parameswaran and Pisharodi, 1992); business, urban planning and design and political sciences (Gertner, 2011); even a blend of geography, marketing, regional studies and tourism (Lucarelli and Brorström, 2013); and tourism (Morgan, Pritchard and Pride, 2010; Ashworth and Kavaratzis, 2010; Moilanen and Rainisto, 2009; Pike, 2008; Beni, 2006). Furthermore, as Lucarelli and Berg (2011, p.22) have suggested for city branding, which can be adjusted to country branding - it is important to treat the phenomena "more as a genuine proper inter-disciplinary domain rather than adopting and borrowing models, concepts and methods from different disciplines”.

A nation brand unquestionably echoes its image abroad or to a target-country using nation branding strategies or not, by just performing its role worldwide, economically. Similarly, a nation creates a brand for itself abroad, whether it intends to or not, simply by performing its role on the global stage. Accordingly, this paper supports the brand as a conveyor of information for economic impact; moreover, the content of the information varies according to the audience the brand is addressing, since "countries, as well as individuals, can be brands" (Lindemann, 2010, p.7). Deliberately or not, a nation's uniqueness transmits its multifaceted image to several audiences regarding its multiple stakeholders (Sevin, 2014; Ruzzier and De Chernatony, 2013; Fetscherin, 
2010; Kavaratzis, 2010; Braun and Zenker, 2010; Jansen, 2008). However, Anholt (2000) and Sevin (2011) states that the place itself needs to change in order to transform its own perception.

Certainly, a place consists in a complex and multidimensional entity (Florek et al., 2006; Dinnie, 2009; Moilanen and Rainisto, 2009; Kavaratzis, 2010; Braun and Zenker, 2010; Zenker, 2011; Warnaby and Medway, 2013; Govers, 2014) in this case, a country itself, which carries beyond tangible and intangible features and associations; and conveys real and imaginative experiences. Furthermore, in order to plan and manage a country brand, the continuous and efficient participation of the government in nation brand actions and place branding strategies are entirely necessary (Govers, 2015; Kotler and Keller, 2012; Go and Govers, 2011; Zenker, 2011; Braun and Zenker, 2010; Dinnie, 2009; Pike, 2008; Anholt, 2007; Beni, 2006; Kavaratziz, 2005; Olins, 2002). Having said that, this paper recalls these available rankings from the chosen country brand indexes in order to explore country brand measurement, knowing that several different stakeholders are involved with the country brand. In view of this complexity, the country brand image may vary across countries as well - affecting meaningfully and varying immensely the country image perceptions as well.

\section{Overview of the Case Study Setting}

In the last two decades, Brazil has been the centre of reflection for studies and discoveries by several authors interested in its intricate and assured revolution - due to its economic growth, its significance in the global marketplace and, certainly, its nature and food resources.

Recent evidence suggests that Brazil is one of the countries attracting considerable attention. Gallup’s website article (2013) is clear and factual about Brazil’s status, "Brazil's economy was, until recently, hailed as a "growth miracle" amid a lethargic global economy". According to the Brazilian Chamber of Commerce in Great Britain (2014), “2014 is definitely Brazil’s year in the spotlight”, not only because the World Cup was hosted there, but also because of the October 
presidential election and because of the nationwide protests in urban centres in June 2013. Moreover, positively, the concessions programme for infrastructure projects continue growing because of the oil and gas industry from the pre-salt fields (Brazilian Chamber of Commerce in Great Britain, 2014).

A number of authors have reported analyses about Brazil's economy that demonstrated Brazil's competitiveness and growth globally (Eakin, 2013; Trebat, 2013; Docksai, 2013). Indeed, Brazil is the world's greenest large economy (Eakin, 2013). However, the country lacks "the basic requirements for economic growth: trust in government institutions, quality of economic infrastructure, access to finance, and the quality of health” (Trebat, 2013, p.131) also education requires further development and progress (Eakin, 2013; Trebat, 2013).

In his recent article, Eakin (2013, p.222) believes books about Brazil are mostly published in order to "explain Brazil"; additionally, he observes that Brazil is no longer destined to be the 'country of the future', as he remarks: "after six presidential elections over the past quarter century, the world's third-largest democracy and sixth-largest economy now has nearly twenty years' experience with low inflation and a level of political stability that few countries in the world can match” (p.221).

Docksai (2013, p.32) observes, “a number of countries’ economies are springing to life and posting even higher employment than they had before the global meltdown. Even more notably, these countries - which include Brazil, Chile, Uruguay, Israel, and Russia, among others-are achieving these results by doing the exact opposite of their wealthier counterparts: Instead of spending less, their governments are spending more”.

A useful example of Brazil's economic growth is from the International Monetary Fund (IMF, 2013) records, whose country-level data on unemployment, Brazil's figures have been declining year a year, from $9.3 \%$ in 2007, followed by 6.7\% in 2010 to $6.0 \%$ in 2012 .

About export status, FIINWEEK (2013) published that Brazil “exports aircraft, automobiles (it is the 4th largest car maker in the world), textiles, footwear, iron ore, steel, coffee, orange juice, 
soybeans and corned beef and ethanol”. Regarding tourism: while South Africa matches Brazil's tourism figures (approximately 5 million each); neither country makes a dent in the world tourism market. Tenth-placed Mexico attracts almost five times more visitors than Brazil does, at 23 million and almost 80 million visitors flock to France every year. If one compares the pristine natural beauty of Brazil and South Africa to those of Mexico and France, one has to ask why these countries attract so few visitors".

According to the World Bank’s (2014) own mission, its focus to help Brazil is related to securing long-term sustainable growth and providing development opportunities for its population. Also the bank guaranteed US\$ 5.8 billion in investments for the first two years with a strong focus on the subnational entities (states and large municipalities) and redoubled support for Brazil's Northeast, the country's poorest region(s). Consequently, the key pillars of the strategy are the following: to strengthen public and private investment; improve service delivery to the poor; strengthen regional and territorial development; and support the effective management of natural resources and the environment (World Bank, 2014).

Mostly, foreign observers recognize Brazil in terms of both positive and negative aspects with its image and associations (Bignami, 2002; Kotler and Keller, 2006; Beni, 2006; Mariutti and Giraldi, 2013) - as discussed next. A few of them are the following: (i) culturally, because of music and dance festivals (samba, bossa nova or carnaval); (ii) tradition because of well-known football players, volleyball titles, Formula One; (iii) famous vacation and sunny destinations, like Rio de Janeiro or Salvador; and/or (iv) economically, as a developing country in South America. Additionally, Terra Brazilis is known globally because of the abundant natural resource exports; maybe because Brazil belongs to the BRICS economic block (Brazil, Russia, India, China, and South Africa) or even because Brazil is the only country in Latin America which does not speak Spanish, but Brazilian Portuguese. As a notable example, Olins (2013) reinforces that one of the most successful products from Brazil, is the Havaianas brand of Brazilian flip-flops, which he says, "are 
taking over the world". Similarly, Dinnie (2016, p.72) mentions that "the footballer Ronaldo as a brand ambassador for Brazil”. Moreover, Eakin (2013, p.229) asks the key question, “when will Brazil finally begin to realize its potential?”

Contrariwise, negative aspects of Brazil's image are known worldwide, for instance, crime, violence, drug dealers, and high level of poverty, among others (Anholt, 2007; Bignami, 2002; Kotler and Gertner, 2004). Likewise, Kotler et al. (1993) has mentioned places which are negatively associated with an already-formed image (e.g. Colombia as the drug capital of South America and Detroit as the murder capital in the United States). Previously, knowledge from some authors has great importance for citing countries which have been trying to improve this country brand management issue despite the type of negative image (or association) they might present (Anholt, 2007). Therefore, Brazil's image is in evidence worldwide and its marketing efforts aim to mitigate or reduce the negative and unattractive aspects in order "to regain public confidence in the wake of the economic crisis overcoming the trust meltdown requires more than vaguely worded marketing practice” (Go and Govers, 2001, p.xi). However, Niesing (2013) supports that Brazil has a relatively good nation image in many dimensions but still has not developed an extensive nation branding strategy. According to Goulart (2015), Brazil’s branding indicates the following drawbacks: low standards of civic engagement, lack of cultural uniformity (due to miscegenation, immigration and the variety of regions, habits, lifestyles), huge social inequality, and a high level of political instability. On the other hand, Tot build on the current knowledge and understanding of Brazil's image it is importance to engage in further research about the country's image. By doing so we can support the nation brand management process and base this understanding on models or indexes which have the potential to build understanding and improve the country's image or core role from a place branding and place management perspective. 


\section{Main Nation Brand Models and Indexes}

Researchers and consultants have introduced measurement models and indexes in both place brand and nation brand for branding strategies (Anholt and Govers, 2014; Zenker, 2011; Fetscherin, 2010; Fombrun, 2010; Anholt, 2007). Likewise, Sevin (2014, p.48) affirms, "scholars have introduced various measurement models in place branding employing various theories and methods”. When considering the purpose, for Sevin, "there are three possible alternatives: (i) employing corporate marketing and branding measures, (ii) adapting corporate marketing and branding measures to place branding context, and (iii) devising models specific to place branding”. Definitely, the place branding model can vary depending on the particular definition of place itself, for instance, city, region, or country, among others. Theoretically and methodologically, research to evaluate a nation brand has has increased in the last decade. However, Zenker (2011, p.41) points out that "the methodical approaches employed by researchers for measuring place brands are usually very limited”. Furthermore, Gertner (2011, p.101) suggests, “place marketing and place branding’ scholars and practitioners must evolve from a descriptive to a normative stage, in the building of a robust theory.” However, for Ruzzier and De Chernatony (2013), there is no model of place brand settled universally. Kavaratzis, (2005), Fetscherin (2010), Lucarelli (2012), Ruzzier and De Chernatony (2013) and Mariutti and Tench (2015) accurately support the need for expanding nation brand models understandings and developments as well. Moreover, it is known that there is a lack of a conventional and wide-ranging theoretical archetype for place branding model (Lucarelli and Brorström, 2013; Gertner, 2011; Zenker, 2011) and country branding model (Govers, 2015; Mariutti and Tench, 2015; Fetscherin, 2010; Dinnie, 2009). On the other hand, a few authors argue that the methodology of city brand rankings is unreliable (Kavaratzis and Ashworth, 2006; cited in Lucarelli and Berg, 2011, p.10), which might be true for country branding.

Brand measurements in place branding may play a significant role for supporting the profitable development of the country itself. Authors have attempted to develop scales or models to 
measure place image as acknowledged by Gertner (2011), Zenker and Martin (2011) or country image (Dinnie, 2009). However, in the view of the two main singular characteristics of places - the diversity of target groups and the complexity multidimensionality per se, a combination of approaches for nation brand measurement is required (Zenker and Martin, 2011).

To date various methods have been developed and introduced to estimate a nation's brand position; however, even though there are several accomplishments to build a straightforward and consistent nation brand model or index in order to strategically convey the corresponding nation image from the desired nation identity, they still lack support and discussion from the arena of nation brand managers, government authorities and researchers. The evidence of advances in nation brand models is exemplified in the recent work undertaken by Anholt and Govers - The Good Country (2014), which measures of "what each country on earth contributes to the common good of humanity and what it takes away” (The Good Country, 2014).

Nation brand indexes are shaped and applied to countries in order to illustrate, evaluate and/or measure a country's position worldwide but also to challenge a country's status. Appropriately, there are reliable models and indexes to evaluate a country's position considering diverse or not variables and dimensions among other countries' profiles, which are from either corporate or scientific origins. Table 1 reflects Brazil's positions in seven of the most recognized models and indexes: 
Table 1. Nation Brand Models and Indexes

\begin{tabular}{|c|c|c|c|}
\hline Model or Index & Author & $\begin{array}{l}\text { Concept Variables } \\
\text { or Dimensions }\end{array}$ & $\begin{array}{l}\text { Brazil } \\
\text { position }\end{array}$ \\
\hline $\begin{array}{l}\text { Anholt-Gfk Roper } \\
\text { Nation Brands Index }\end{array}$ & Simon Anholt & $\begin{array}{l}\text { Exports, Governance, Culture and } \\
\text { Heritage, People, Investment and } \\
\text { Immigration and Tourism }\end{array}$ & $\begin{array}{l}\mathbf{2 0}^{\text {th }} \text { among } \\
50 \text { nations } \\
\text { in } 2010\end{array}$ \\
\hline $\begin{array}{l}\text { Country Brand } \\
\text { Strength Index - } \\
\text { CBSI }\end{array}$ & Mark Fetscherin & $\begin{array}{l}\text { Export, Tourism, FDI, Immigration and } \\
\text { Governance }\end{array}$ & $\begin{array}{l}\mathbf{2 8}^{\text {th }} \text { among } \\
44 \text { nations } \\
\text { in } 2011\end{array}$ \\
\hline Country RepTrak & Charles Fombrun & $\begin{array}{l}\text { Advanced Economy, Appealing } \\
\text { Environment, Effective Government, } \\
\text { Supportive Behaviour Dimensions and } \\
\text { Self-Image }\end{array}$ & $\begin{array}{l}\mathbf{2 1}^{\text {st }} \text { among } \\
35 \text { nations } \\
\text { in } 2014\end{array}$ \\
\hline $\begin{array}{l}\text { The East West } \\
\text { Nation Brand } \\
\text { Perception Indexes } \\
\text { and Reports }\end{array}$ & $\begin{array}{l}\text { East West } \\
\text { Communications, } \\
\text { Experts } \\
\text { Perceptions } \\
\text { Metrics }\end{array}$ & $\begin{array}{l}\text { Analysing countries from news articles. } \\
\text { Global media sources were surveyed } \\
\text { between - almost } 5 \text { million references. } \\
\text { The score relies both on the overall } \\
\text { quality of the media and the prominence } \\
\text { of the country, determined by the number } \\
\text { of country references or mentions. }\end{array}$ & $\begin{array}{l}\mathbf{1 8 3}^{\text {th }} \text { among } \\
200 \text { nations } \\
\text { in } 2011\end{array}$ \\
\hline $\begin{array}{l}\text { The FutureBrand } \\
\text { Country Brand } \\
\text { Index }\end{array}$ & $\begin{array}{l}\text { The FutureBrand } \\
\text { Team }\end{array}$ & $\begin{array}{l}\text { Quality of Life, Value System, Heritage } \\
\text { and Culture, Good for Business and } \\
\text { Tourism }\end{array}$ & $\begin{array}{l}\mathbf{2 8}^{\text {th }} \text { among } \\
118 \text { nations } \\
\text { in } 2011\end{array}$ \\
\hline $\begin{array}{l}\text { The Global Peace } \\
\text { Index }\end{array}$ & $\begin{array}{l}\text { UK Peace } \\
\text { Institute for } \\
\text { Economics and } \\
\text { Peace }\end{array}$ & $\begin{array}{l}\text { Twenty three indicators considering } \\
\text { Internal Peace and External Peace }\end{array}$ & $\begin{array}{l}\mathbf{8 1}^{\text {th }} \text { among } \\
162 \text { nations - } \\
\text { medium level } \\
\text { in } 2010\end{array}$ \\
\hline The Good Country & $\begin{array}{l}\text { Anholt and } \\
\text { Govers }\end{array}$ & $\begin{array}{l}\text { Science and Technology, Culture, } \\
\text { International Peace and Security, World } \\
\text { Order, Planet and Climate, Prosperity and } \\
\text { Equality, Health and Wellbeing }\end{array}$ & $\begin{array}{l}\mathbf{4 9}^{\text {th }} \text { among } \\
125 \text { nations } \\
\text { in } 2014\end{array}$ \\
\hline
\end{tabular}

Source: Developed from Go and Gover (2011) and from the institutes’ websites $(2013,2014)$.

Clearly, the chart above shows that Brazil's position in each model varies. Collectively, they evidence the unbalanced outcomes from studies, which search for the similar aim of measuring a nation brand. However, each index has its own main purposes, which applies specific data collection, samples, and rationale design and research approaches. They are noticeably composed by different dimensions or variables; even though there are also a few similar dimensions. For these reasons, four out of the seven models and indexes are selected to be analysed in this paper, in the following section.

Besides those specific nation brand models and indexes, there are other measurements and evaluations about a country brand image or reputation, its development and success, which can contribute to a nation's improvement, progress, and planning. They are worth considering for 
different objectives, for instance: the Gross Domestic Product (GDP), The Competitiveness Indexes by the World Economic Forum, the Human Development Index (HDI), and, Gallup poll (public domain) and the United Nations statistics and reports. Overall, this paper also contributes to the reflection on the critical studies perspective of the contemporary theoretical structure of the place branding research domain, discussed by Lucarelli and Berg (2011) in relation to city branding, which can be applied to country branding as well. Appropriately, the critical studies perspective, whether or not alongside the other two emerging perspectives - branding as production and branding as appropriation - examines whether country branding represents a positive or negative factor for the economic, social, and cultural environment.

\section{Methodology}

Regarding methodology, exploratory qualitative approach was chosen along with secondary data collection (Neuman, 2014) provided by the index websites online. Thus, a single case study using Brazil’s brand as unit of analysis was carried out for in-depth investigation of the phenomenon in its global context (Yin, 2012). Therefore, the categorical data are from Brazil's positions in four indexes, being beneficial because they corroborate evidence from different sources (Yin, 2012). The use of 'word tables' for comparative methods can create robust evidence and visual interpretation as well. As suggested by Yin (2012), when the phenomena is not readily distinguishable from its context - exactly in this paper when the roots of nation brand are grounded in several key disciplines that have established this multidimensional construct which is in constant transformation due to global competitiveness and connectivity and, sustainability concerns. Moreover, critical studies are emerging in the research domain of place (country) branding as a positive / negative phenomena (Lucarelli and Berg, 2011, p.18). 


\section{Comparing Brazil's Positions from the Selected Indexes}

There are four main reasons to select these nation brand indexes. Firstly, due to their accepted popularity in the field of place branding, nation brand and country reputation studies. Second, they are publicly available online; third, they comprehensively cover substantial and genuine data. Forth, they are examples for this study because of the limitation of the field: the absence of a comprehensive measurement for place branding (Lucarelli and Brorström, 2013; Zenker and Martin, 2011; Gertner, 2011; Zenker, 2011) and country branding model (Govers, 2015; Mariutti and Tench, 2015; Fetscherin, 2010; Dinnie, 2009).

This study examines and describes four nation brand indexes to evaluate Brazil's position as a case study using the indexes by Anholt (2007) Fetscherin (2010), Fombrun (2014) and Anholt and Govers (2014). They are each reviewed and compared in detail to understand their approach and methods. Additionally, this study is unique in applying Brazil as a case to evaluate the country's position in four different indexes. These four indexes were chosen because they partially are the most similar concerning their dimensions, their specific aims as well as thier methodological approaches regarding sampling, instruments, types of data collection and research design.

Accordingly, the main characteristics obtained from the overall examination of the four indexes are presented next on Table (2). In summary, these outcomes show that there are visible similarities, however, diverse approaches are also found. 
Table 2. Ranking Comparisons

\begin{tabular}{|c|c|c|c|c|}
\hline 苞 & $\begin{array}{l}\text { The Anholt-Gfk } \\
\text { Roper Nation } \\
\text { Brands Index } \\
\text { (Simon Anholt, } \\
\text { 2007) } \\
\end{array}$ & $\begin{array}{l}\text { Country Brand } \\
\text { Strength Index } \\
\text { (Mark Fetscherin, } \\
\text { 2010) }\end{array}$ & $\begin{array}{l}\text { Country RepTrak } \\
\text { - Reputation Institute } \\
\text { (Charles Fombrun, } \\
\text { 2014) }\end{array}$ & $\begin{array}{l}\text { The Good Country } \\
\text { Index } \\
\text { (Simon Anholt and } \\
\text { Robert Govers, 2014) }\end{array}$ \\
\hline 总 & $\begin{array}{l}\text { Culture and Heritage } \\
\text { Exports } \\
\text { Governance } \\
\text { Immigration } \\
\text { Investment } \\
\text { People } \\
\text { Tourism }\end{array}$ & $\begin{array}{l}\text { Export } \\
\text { Foreign Direct } \\
\text { Investment } \\
\text { Governance } \\
\text { Immigration } \\
\text { Tourism }\end{array}$ & $\begin{array}{l}\text { Advanced Economy } \\
\text { Appealing Environment } \\
\text { Effective Government } \\
\text { Self-Image } \\
\text { Supportive Behaviour } \\
\text { Dimensions }\end{array}$ & $\begin{array}{l}\text { Culture } \\
\text { International Peace and } \\
\text { Security } \\
\text { Planet and Climate } \\
\text { Prosperity and Equality } \\
\text { Health and Wellbeing } \\
\text { Science and Technology } \\
\text { World Order }\end{array}$ \\
\hline 羿 & $\begin{array}{l}\text { It measures the } \\
\text { perception of people } \\
\text { about a country }\end{array}$ & $\begin{array}{l}\text { It measures how the } \\
\text { country performs }\end{array}$ & $\begin{array}{l}\text { It analyses the various } \\
\text { perceptions of a country } \\
\text { measured by various } \\
\text { stakeholder groups }\end{array}$ & $\begin{array}{l}\text { It measures what each } \\
\text { country contributes to } \\
\text { the common good of } \\
\text { humanity }\end{array}$ \\
\hline 苞 & Primary data & Secondary data & Primary data & Secondary data \\
\hline ڤัٌ & $\begin{array}{l}\text { Survey with nearly } \\
20,000 \text { people in } 20 \\
\text { countries each year }\end{array}$ & $\begin{array}{l}\text { World Bank } \\
\text { United Nations } \\
\text { Reports } \\
\text { Li and Filler (2007) }\end{array}$ & $\begin{array}{l}\text { Online interviews with } \\
\text { more than } 27,000 \\
\text { consumers in the G8 } \\
\text { countries }\end{array}$ & $\begin{array}{l}\text { A wide range of data } \\
\text { from the United Nations } \\
\text { and other international } \\
\text { organisations }\end{array}$ \\
\hline 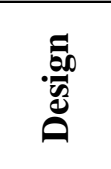 & $\begin{array}{l}40 \text { questions about } \\
\text { their perceptions of a } \\
\text { country }\end{array}$ & $\begin{array}{l}\text { Based on an } \\
\text { equation: } \\
\quad \text { CBSI }_{i}=\frac{E_{i}}{x_{i}}+\frac{T_{i}}{x_{i}}+\frac{F_{i}}{x_{i}}+\frac{M_{i}}{x_{i}}+G_{i}=\end{array}$ & $\begin{array}{l}\text { Global study of more } \\
\text { than } 34,000 \text { ratings }\end{array}$ & $\begin{array}{l}\text { Overall rank is based on } \\
\text { the average of the } \\
\text { category ranks }\end{array}$ \\
\hline 愙 & 50 countries & 31 countries & 55 countries & 125 countries \\
\hline 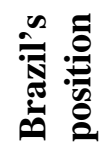 & $20^{\text {th }}(2010)$ & $28^{\text {th }}(2011)$ & $21^{\text {st }}(2014)$ & $49^{\text {th }}(2014)$ \\
\hline
\end{tabular}

For Fetscherin (2010), both his index and Anholt's have their roots from corporate branding principles even though Anholt's Index originates from place branding and public diplomacy issues. Fetscherin (2010, p.466) upholds, "The two indexes are highly and significantly correlated, indicating they measure the same phenomena, although they use different approaches, methodologies, and data, suggesting that the indexes are complementary and inter-dependent”. 


\section{The Anholt-Gfk Roper Nation Brands Index (NBI)}

Unquestionably, Simon Anholt - in 1998 - has established the field milestone shaping the knowledge of nation brand, about nations of the twenty-first century, focusing on the reputation of the countries and their prosperity. Since then, Anholt's Index is recognized both in the corporate and academic arenas worldwide. The NBI presents the following dimensions: Exports, Governance, Culture and Heritage, People, Investment and Immigration and Tourism. It means that the three dimensions of the critical studies - economic, social and cultural - are considered (Lucarelli and Berg, 2011). Anholt developed the Nation Brands Index in 2005 as a way to measure the image and reputation of the world's nations, and to track their profiles as they rise or fall. However, in 2007, Anholt's Hexagon approach concentrates on his conceptual terminology called Competitive Identity, which is more focused on national identity and public diplomacy. Public diplomacy, government interests and politics integrations are for all intents and purposes related to the role of a "brand management as a component of national policy” mentioned by Dinnie (2009, p.32) and agreed by Szondi (2007).

Later on, in partnership with GfK Roper Public Affairs and Media, Anholt launched an expanded Nation Brands Index. For Sevin (2014, p.49), since Anholt's Index “is a commercial product, therefore its methods and surveys are not transparent”. Moreover, Anholt’s Index definition of brand is described by Sevin as “dominantly based on reputation and brand image” (2014, p.49), which is supported in papers by Mariutti and Giraldi (2013), Dinnie (2009) and Kavaratziz (2005).

\section{Country Brand Strength Index (CBSI)}

According to Fetscherin (2010, p.466) his "index represents an alternative measurement to the existing subjective survey-based measurement indexes”, which was inspired by previous studies (Shimp et al., 1993; Anholt, 1998; Cho and Shu, 2006). Fetscherin (2010, p.468) adds: "Because country branding is unusually complex, we do not claim that our index accounts for all dimensions of country branding. However, it is a starting point and an alternative measurement with a 
transparent approach and methodology based on objective secondary data. Our proposed index is designed to be manageable and straightforward yet still yield meaningful results.”

The CBSI by Fetscherin (2010) presents the following dimensions: Export, Tourism, Foreign Direct Investment, Immigration, and Governance - collected by secondary sources and calculated in 31 countries. A high CBSI score indicates a strong country brand while a low CBSI score indicates a weak country brand. In our sample, Ireland has the highest score (i.e. the strongest country brand) and China has the lowest score (the weakest country brand). Looking at the dimensions shows that only one dimension of the critical studies perspective in place branding (Lucarelli and Berg, 2011) is covered: the economic. For Fetscherin (2010, p.475), comparing his own index with Anholt's index, he outlines, "each has its strengths and weaknesses and one should probably consider both indexes for accurate insight into a country’s brand. Combining both indexes might help countries assess their country brand, how people perceive it, and how well it performs in terms of exports, tourism, investment, and immigration. A combined index might help identify any perception-actuality gap”.

\section{Country RepTrak}

Country RepTrak has its roots in corporate reputation research, which has experience in advising global organizations over 25 years - the Reputation Institute is the world's leading reputation-based advisory firm, founded by Charles Fombrun and Cees van Riel in 1997 (Country RepTrak, 2014). The Country RepTrak is collected from more than 27,000 consumers in the G8 countries (Canada, France, Germany, Italy, Japan, Russia, United Kingdom, and the United States of America). In 2013, Canada takes top spot for a third consecutive year with Sweden and Switzerland to make the top three in this year's list of the World's Most Reputable Countries (Country RepTrak, 2014). Regarding Brazil's status, it has proved its reputation significantly in the last year, exact $4.2 \%$, which means the highest one from the BRICS' countries (Country RepTrak, 2014). However, Brazil, which is in the 
$21^{\text {st }}$ position, is in the weak reputation category between the countries in the $20^{\text {th }}$ and $48^{\text {th }}$ positions (Country RepTrak, 2014).

The dimensions are the following: Effective Government, Advanced Economy, Appealing Environment, Supportive Behaviour Dimensions and Self-Image. This means that the three dimensions of the critical studies - economic, social and cultural - are included (Lucarelli and Berg, 2011).

For the Country RepTrak (2014), the two relevant aims are the following. First, the positive reputation reduces the cost of debt, for instance, "countries that enjoy a solid reputation are able to finance themselves in the international markets at a lower cost than countries with a weak reputation". Secondly, the key reputation drivers for influencing stakeholder behaviour is "being perceived as a country that has a good business environment is essential for attracting foreign investment and human talent, while a population that is seen as friendly and welcoming contributes to people's intention to visit a country, study there and the decision to buy its products and services” (Country RepTrak, 2014).

The insights generated through the Country RepTrak study can also help country governments in several issues. For instance, the governments could "establish key performance indicators that support a country's brand and reputation initiatives; to inform strategic marketing campaigns to grow tourism and business development; to identify weak reputational areas for improvement and positive areas to leverage; positive country data results can be used to build national pride, marketing leverage, and influence the reputation of local company brands” (Country RepTrak, 2014). In addition, it supports governments to "advise corporations on going global and how to efficiently build relationships with key stakeholders in the most vital country markets; to identify and understand the impact of country reputations on corporate brands”. Finally, the index "realize the impact of supportive behaviours in the forms of buying, working, and investing in a specific country of interest” (Country RepTrak, 2014). 


\section{The Good Country Index (GCI)}

Due to its distinction initiative and multiple formulations in relation to the previous four indexes, the Good Country Index is presented in this paper as a resourceful, critical, and insightful intention mostly because the GCI is incomparable due to its fundamentally ethical and liable features. It presents a unique and ground breaking nation measurement in regards to measuring what each “country contributes to the greater good” (The Good Country, 2014). Moreover, the Index aims “to start a global discussion about how countries can balance their duty to their own citizens with their responsibility to the wider world, because this is essential for the future of humanity and the health of our planet” (The Good Country, 2014). For this index, the GCI uses a wide range of data from the United Nations and other international organisations. The purpose is to communicate that: "people who see global issues as just as important or even more important than national issues; who are more concerned with international co-operation and human progress than with domestic politics; people who see their humanity as more important than their nationality” (The Good Country, 2014).

Thus, after exploring the GCI for this comparative study, Brazil’s positions are revealed in each dimension and the top-three countries as well - as Table 3 below demonstrate.

Table 3. Brazil's position at The Good Country Index

\begin{tabular}{|c|c|l|}
\hline Dimension & Brazil's position & \multicolumn{1}{|c|}{ First-three countries } \\
\hline Planet and Climate & $5^{\text {th }}$ & Iceland, Canada and Sweden \\
\hline World Order & $37^{\text {th }}$ & Germany, Austria and Netherlands \\
\hline Culture & $49^{\text {th }}$ & Belgium, Netherlands and Malta \\
\hline Health and Wellbeing & $52^{\text {nd }}$ & Spain, Netherlands and Belgium \\
\hline Science and Technology & $75^{\text {th }}$ & United Kingdom, Austria and Cyprus \\
\hline International Peace and Security & $83^{\text {rd }}$ & Egypt, Jordan and Tanzania \\
\hline Prosperity and Equality & $123^{\text {rd }}$ & Ireland, Switzerland and Finland \\
\hline
\end{tabular}

Source: Structured by the author based on The Good Country (2014)

These dimensions can indicate in which aspects Brazil should progress internally and advance internationally in order to generate the country's welfare and enhance the country image abroad, respectively and reciprocally. Each dimension is described next according to The Good 
Country Index (2014). Planet and Climate constitutes of biocapacity reserve, hazardous waste exports, organic water pollutant emissions, $\mathrm{CO}_{2}$ emissions and other greenhouse gas emissions. World Order includes charity giving, refugees' hosts, refugees generated, population growth, and UN Treats signed. Culture represents the creative goods exported, creative services exported, UNESCO dues in arrears, freedom of movement, and press freedom. Health and Wellbeing represents food aid, pharmaceutical exports, voluntary excess donations to the WHO, humanitarian aid donations and drug seizures. Science and Technology represents international students, journal exports, international publications, Nobel prizes, and patents. International Peace and Security represents peacekeeping troops, dues to arrears to UN peace-keeping budgets, international violent conflict, arms exports and internet security. Prosperity and Equality represents open trading, UN volunteers abroad, fairtrade market size, FDI outflows and development assistance.

\section{Discussion}

As stated by Zenker (2011), place brand models and indexes are not always entirely precise, but are nevertheless beneficial for research and theory development, therefore this paper attempts to present seven nation and describe four brand indexes which all try to define a country brand status quo. As mentioned in the literature review, these seven nation models and indexes were established by innovative approaches and differentiated methods in order to measure or position a nation's brand globally over the last decade. This paper has demonstrated, for the first time, that one nation can be ranked differently or not in these seven well-recognized nation brand models and indexes - because each of them establish different dimensions, have particular aims and apply diverse methods.

However, on the fragmented world setting, the critical studies perspectives in the contemporary theoretical structure of the research domain in place branding (Lucarelli and Berg, 2011) may enlighten country branding efforts - thus, together these main models and indexes provide critical insights into the nation brand theme, regarding their own main dimensions. Moreover, these 
models and indexes provide evidence about one nation's singularities, for instance, each country's status quo concerning its economic situation, not considering if the country is an emergent or emerging country - they are positioned in the whole ranking altogether.

Collectively, they all have specific purposes as detailed next. Certainly, two of them are precise in their exact aims, the Global Peace Index (2014), which is strictly peace-oriented and; the East West Nation Brand Index, which is essentially originated from perceptions of countries in the media, based on 193 United Nations members and how they are described in major international media outlets.

The latest model The Good Country Index - GCI - focuses on measuring what each country has contributed to "the common good of humanity" (The Good Country, 2014). Based in this core aim, the Future Brand, RepTrak and the Global Peace Index demonstrate a slight convergence regarding their dimensions.

Moreover, the GCI is the only model which complements the emerging critical studies perspective on the contemporary theoretical structure of the research domain (Lucarelli and Berg, 2011) and is also aligned to one of this paper's contributions. As in country branding, a positive/negative factor for the economic, social, and cultural environment could also be understood as country brand dimensions, besides the overall country branding. Moreover, the other two perspectives, branding as production and branding as appropriation, could be integrated into the weaknesses and the strengths of the seven dimensions as reported in the GCI for a country's positions (Table 3). For instance, Brazil has a top rank $\left(5^{\text {th }}\right)$ in the 'Planet and Climate' dimension, which means major positive actions in sustainable and environmental issues are being made in the country regarding bio capacity reserve, hazardous waste exports, water pollution, CO2 emissions and other greenhouse gas emissions. On the other hand, in regards to 'International Peace and Security', Brazil reported a lower rank internationally $\left(83^{\text {rd }}\right)$ and this aligns with the literature regarding Brazil’s image (Anholt, 2007; Beni, 2006; Bignami, 2002; Kotler and Gertner, 2004; Kotler and 
Keller, 2006; Mariutti and Giraldi, 2013). In the dimension of 'Prosperity and Equality', Brazil shows the worse rank $\left(123^{\text {rd }}\right)$ in regards to opening trade, UN volunteers abroad, Fair Trade market size, Foreign Direct Investment (FDI) outflow and development assistance. This means attention should be given to the country's progress in regards to both prosperity and equality development, which will improve Brazil’s country brand image as well.

Two of the indexes are mostly consultancy-oriented, Anholt's Index (2007) and The FutureBrand's Index (2005). One of them was launched from a theory-related index, the Reputation Quotient by Harris and Fombrun (2014) and has become a more business-oriented tool, Country RepTrak (2014). RepTrak (2010) is the only one which analyses the perceptions of a country measured by several stakeholders, agreeing with the literature's evidence about its significance for nation brand, which is supported by several authors (Sevin, 2014; Ruzzier and De Chernatony, 2013; Fetscherin, 2010; Kavaratzis, 2010; Braun and Zenker, 2010; Jansen, 2008).

Furthermore, after being compared, the selected indexes by Anholt (2007), Fetscherin (2010), and Fombrun (2014) demonstrate that they are more similar in structure and method as previously stated. A strong relationship between Anholt’s Index (2007) and Fombrun's RepTrak (2010) has been found in this paper because they both measure the perceptions about a nation. Based on the indexes' profile, the study has demonstrated that NBI and RepTrak models have three identical features. First, they both use additional dimensions, yet unlike the NBI adds 'Culture and Heritage' and 'People’; and RepTrak adds 'Supportive Behaviour Dimensions’ and 'Self-Image’. Secondly, concerning data collected, they are both analysed using primary data with surveys applied in foreign countries. Thirdly, they both study 50 countries. However, both NBI and RepTrak place Brazil in the closest positions, respectively, $20^{\text {th }}$ and $21^{\text {st }}$. Possibly, one reason for this fact can be related to the two last similarities - using supplementary dimensions and primary data collection.

Considering the index authors’ individual discipline and academic profiles, it is noteworthy that Fombrun (2014) has intensely researched corporate reputation and brings with him academic 
knowledge and background from the field of public relations. Anholt (2007) has his roots in a consultancy viewpoint in public diplomacy and place branding principles. Fetscherim (2010) comes from an international business and branding academic experience standpoint.

Yet, comparing dimensions from Anholt’s Index (2007) and Fetscherin’s Index (2010), they are the most similar ones. On the other hand, Fetscherin’s Index (2010) and The FutureBrand (2005) support the same position for Brazil, the $28^{\text {th }}$ on their ranking, even though they have used only two similar dimensions - Tourism and Business (FDI/Export) and have investigated a different total number of countries.

It is important to bear in mind the possible misinterpretations about the rankings' profile, mostly because the data collecting instruments' content is not available and the data analysis is not well described in every index. These findings suggest that a nation brand can be viewed inconsistently in the rankings and produce diverse interpretations in nation brand models and indexes with similarities and connections due to the reality that a country is a multiplex system and branding is a constantly evolving process (Florek et al., 2006). Moreover, due to the lack of appropriate conceptualization of a country brand, which employs different measurement approaches for the different elements of the brand (Zenker, 2011), measuring a country brand, perhaps, might be an endless research challenge.

Certainly, the findings can help to guide nation brand managers and researchers to distinguish each nation brand index when analysing the complex image of place brand and managing the country brand image with the participation of the government, as suggested by several authors in the field (Govers, 2015; Kotler and Keller, 2012; Go and Govers, 2011; Zenker, 2011; Braun and Zenker, 2010; Dinnie, 2009; Pike, 2008; Anholt, 2007; Beni, 2006; Kavaratziz, 2005; Olins, 2002).

The results of this research support the idea that the nation indexes are complementary and they do contribute in challenging the responsibility of understanding a nation's brand construct 
around multiple stakeholders to build understanding of sustainable nations and the connectivity of the global marketplace.

Further research in this field would be advantageous if applied to other nations, regarding their own distinctiveness and context, for foundation knowledge, certainly when theoretically based on the emerging perspective of the critical studies (Lucarelli and Berg, 2011) for country brands and country branding cases. Additionally, the use of these types of secondary data as support for comparative studies between countries could be a means of advancing and challenging nation brand research not only for the literature but also for the world's future wellbeing. A global discussion as initiated by The Good Country (2014) is currently crucial regarding "how countries can balance their duty to their own citizens with their responsibility to the wider world, because this is essential for the future of humanity and the health of our planet”.

\section{References}

Anholt, S. (2000) The nation as a brand. Across the Board, 37 (10): 22-27.

Anholt, S. (2007) Competitive Identity: The New Brand Management for Nations, Cities and Regions. New York: Palgrave Macmillan.

Anholt, S. (2010) The Anholt-GfK Roper City Brands Index. http://www.simonanholt.com/Research/research-the-anholt-gfk-roper-nation-brands-index-sm.aspx. Accessed 10 October 2014.

Anholt, S. and Govers, R. (2014) The Good Country. http://www.goodcountry.org/ Accessed 10 September 2014.

Ashworth, G. and Kavaratziz, M. (eds) (2010) Towards Effective Place Brand Management. Northampton: Edward Elgar Publishing.

Beni, M. C. (2006) Politics and Tourism Planning in Brazil [in Brazilian Portuguese] São Paulo: Aleph. Bignami, R. (2002) Brazil’s Image in Tourism [in Brazilian Portuguese] São Paulo: Aleph.

Braun, E. and Zenker, S. (2010) Towards an Integrated Approach for Brand Management. Proceedings of the $50^{\text {th }}$ European Regional Science Association Congress. Jonkoping, Sweden, 1923 August.

Brazilian Chamber of Commerce in Great Britain (2014) Brazil Business Brief. http://brazilianchamber.org.uk/. Accessed 10 January 2015. 
Buhmann, A. and Ingenhoff, D. (2013) Advancing the Country Image Construct from a Public Relations Perspective: The Constitution of the County Image and its Effect on Travel Behaviour. Proceedings of EUPRERA 2013 Congress, Barcelona, Spain.

Cevero, R. (2013) The FutureBrand Country Index: Country Brand Index 2012-13.

http://www.futurebrand.com/images/uploads/studies/cbi/CBI_2012-Final.pdf . Accessed 21 October 2014.

Country RepTrak (2014) Managing Your Country's Reputation with 2013 Country RepTrak. $<$ http://www.reputationinstitute.com/thought-leadership/country-reptrak>. Accessed 10 January 2015.

Dinnie, K. (2016) Nation Branding: Concepts, Issues, Practice. $2^{\text {nd }}$ edition. Oxon: Routledge.

Dinnie, K. (2009) Nation Branding: Concepts, Issues, Practice. Oxford: Elsevier.

Docksai, R. (2013) Five Economies That Work: Global Success Stories, The Futurist, March- pp.3239. http://blogs.ugto.mx/business/wp-content/uploads/sites/10/2014/07/85194638.pdf. Accessed 24 January 2015.

Eakin, M.C. (2013) The Emergence of Brazil on the World Stage. Latin American Research Review, 48 (3): 221-230, doi: 10.1353/lar.2013.0044

Fetscherin, M. (2010) The determinants and measurement of a country brand: the country brand strength index. International Marketing Review, 27 (4): 466-479, doi:

http://dx.doi.org/10.1108/02651331011058617

FIINWEEK (2013) Rebuilding the World Economy BRIC(S) by brick. April $11^{\text {th }}$. http://finweek.com/tag/brics/. Accessed 16 March 2014.

Florek, M., Insch, A. and Gnoth, J. (2006) City Council websites as a means of place brand identity communication. Place Branding and Public Diplomacy, (2) 4: 276-296, doi:

10.1057/palgrave.pb.6000036.

Fombrun, C.J. (2014) Country RepTrak.

http://www.reputationinstitute.com/thought-leadership/country-reptrak. Accessed 21 December 2014.

Gallup (2013) Brazil's Growth Could Use a Boost.

http://businessjournal.gallup.com/content/165650/brazil-growth-boost.aspx. Accessed 22 November 2014.

Gertner, D. (2011) Unfolding and configuring two decades of research and publications on place marketing and place branding. Place Branding and Public Diplomacy, 7 (2): 91-106, doi:10.1057/pb.2011.7

Go, F.M. and Govers, R. (eds) (2011) International place branding yearbook 2011: managing reputational risk. Individual chapter’s contributors. London: Palgrave Macmillan. 
Goulart, R. (2015) Place Brand Observer. Interview with Raquel Goulart.

$<$ http://placebrandobserver.com/interview-raquel-goulart-sztejnberg-brazil-place-branding-expert/

$>$ Accessed on August 62015

Govers, R. (2015) Place Brand Observer. Interview with Rober Govers.

http://placebrandobserver.com/interview-robert-govers-on-place-branding-research-and-practice/ Accessed on 5 March 2015.

IMF (2014) International Monetary Fund. http://www.imf.org/external/pubs/ft/weo/2014/01/?, Accessed 22 August 2014.

Jansen, S.C. (2008) Designer nations: Neo-liberal nation branding - Brand Estonia. Social Identities, (14) 1: 121-142, doi: 10.1080/13504630701848721.

Kavaratziz, M. (2005) Place Branding: A Review of Trends and Conceptual Models. The Marketing Review, 5 (4): 329-342, doi: http://dx.doi.org/10.1362/146934705775186854.

Kavaratziz, M. (ed) (2010) Place branding: where do we stand? In: G.Ashworth and M.Kavaratziz (eds). Towards Effective Place Brand Management. Northampton: Edward Elgar Publishing, pp.114.

Kotler, P. and Gertner, D. (2004) Country as brand, product, and beyond: A place marketing and brand management perspective. In: N.Morgan, A.Pritchard, R.Pride (eds). Destination Branding: Creating the Unique Destination Proposition. Oxford and Burlington: Elsevier. pp.40-56

Kotler, P. and Keller, K.L. (2006) Marketing Management. $12^{\text {nd }}$ edition. São Paulo: Pearson Prentice Hall.

Kotler, P.; Haider, D. and Rein, I. (1993) Marketing Places: Attracting Investment, Industry, and Tourism to Cities, States, and Nations. New York: The Free Press.

Lindemann, J. (2010) The Economy of Brands. New York: Palgrave Macmillan.

Lucarelli, A. and Brorström, S. (2013) Problematizing place branding research: A meta-theoretical analysis of the literature. The Marketing Review, 13 (1): 65-81, doi:

10.1362/146934713X13590250137826.

Lucarelli, A. and Berg, P.O. (2011) City Branding: A State-of-Art Review of the Research Domain. Journal of Place Management and Development, 4 (1): 9-27.

Mariutti, F.G. and Giraldi, J.M.E. (2013) Country Brand Identity: Communication of the Brazil Brand in the United States of America. Saarbrucken: LPA Academic Publishing.

Mariutti, F.G. and Tench, R. (2015) Are we Talking the Same Language? Challenging Complexity in Country Brand Models. Athens Journal of Business and Economics, 1 (1): 49-61.

Moilanen, T. and Rainisto, S. (2009) How to brand nations, cities and destinations: a planning book for place branding. London: Palgrave Macmillan. 
Neuman, W.L. (2014) Social research methods: qualitative and quantitative approaches. $7^{\text {th }}$ ed. Essex: Pearson.

Niesing, E. (2013) Latin America's Potential in Nation Branding: A closer look at Brazil's, Chile's and Colombia's practices. Hamburg: Anchor Academic Publishing.

Olins, W. (2013) Nation Branding. Lecture at the CI-Convention on Nation Branding, in Graz. https://www.youtube.com/watch?v=Bc-N1Upvgr8andapp=desktop, Accessed 4 November 2013.

Olins, W. (2002). Branding the nation - The historical context, Journal of Brand Management, 9 (45): 241-248.

Papadopoulos, N. and Heslop, L. (1993) Product-Country Images: Impact and Role in International Marketing. New York: Haworth Press.

Parameswaran, R. and Pisharodi, R. (1992) Confirmatory Factor Analysis of a Country-Of-Origin Scale: Initial Results. Advances in Consumer Research, 19: 706-714.

Pike, S. (2008) Destination marketing: an integrated marketing communication approach. Oxford: Elsevier.

Roth, K.P. and Diamantopoulos, A. (2008) Advancing the country image construct. Journal of Business Research, 62: 726-740, doi:10.1016/j.jbusres.2008.05.014.

Ruzzier, M.K. and De Chernatony, L. (2013) Developing and applying a place brand identity model: The case of Slovenia, Journal of Business Research, 66 (1): 45-52, doi:10.1016/j.jbusres.2012.05.023.

Sevin, E. (2011) Thinking about place branding: Ethics of concept. Place Branding and Public Diplomacy, 7 (3): 155-164, doi:10.1057/pb.2011.15.

Sevin, H.E. (2014) Understanding cities through city brands: City branding as a social and semantic network. Cities, 38 (5): 47-56, doi:10.1016/j.cities.2014.01.003.

Szondi, G. (2007) The role and challenges of country branding in transition countries: The Central and Eastern European experience, Place Branding and Public Diplomacy, 3 (1): 8-20, doi:10.1057/palgrave.pb.6000044.

The East West Nation Brand Perception Indexes and Reports (2013) http://www.eastwestcoms.com/global.htm, Accessed 21 October 2014.

The Global Peace Index Report (2014) Brazil. http://www.visionofhumanity.org/pdf/gpi/2013_Global_Peace_Index_Report.pdf, Accessed 21 October 2014.

The Good Country (2014) http://www.goodcountry.org/ Accessed 10 September 2014.

Trebat, T.J. (2013) New Directions for a More Prosperous Brazil. Journal of International Affairs, Spring/Summer 2013, 66 (2): 127-142. 
Warnaby, G. and Medway, D. (2013) What about the 'place' in place marketing? Marketing Theory, 13 (3): 345-363, doi: 10.1177/1470593113492992

World Bank (2014) Brazil. http:/data.worldnamk.org, Accessed 10 September 2014.

Yin, R. K. (2012) Applications of case study research. $3^{\text {rd }}$ edition. London: Sage.

Zenker, S. (2011) How to catch a city? The concept and measurement of place brands. Journal of Place Management and Development, 4 (1): 40-52.

Zenker, S. and Martin, N. (2011) Measuring success in place marketing and branding. Place Branding and Public Diplomacy, 7, 32 - 41, doi: 10.1057/pb.2011.5 